\title{
Corrosion Behaviour of 1018, 410 and 800 Steels in Synthetic Wastewater
}

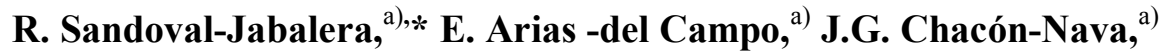 \\ J.M. Malo-Tamayo, ${ }^{\text {b) }}$ A. Martínez-Villafañe ${ }^{\text {a) }}$ \\ a) Advanced Materials Research Centre, Division of Materials Deterioration and Structural \\ Integrity, Miguel de Cervantes 120, Complejo Ind. Chihuahua, \\ C.P. 31109, Chihuahua, Chih. México \\ ${ }^{b)}$ Electrical Research Institute, Mechanical Systems Division, Av. Reforma, C.P. 62490, \\ Cuernavaca, Mor. México
}

Received 22 November 2004; accepted November 2006

\begin{abstract}
The corrosion behaviour of 1018,410 and 800 steels exposed to synthetic wastewater has been studied using linear polarization resistance (LPR), cyclic potentiodynamic curves (CPC), electrochemical noise (EN), and electrochemical impedance spectroscopy (EIS) tests. The conditions were: biochemical oxygen demand (BOD) of $776 \mathrm{ppm}$, a chemical oxygen demand (COD) of $1293 \mathrm{ppm}, \mathrm{pH}=8$ and the cell temperature was 24 ${ }^{\circ} \mathrm{C}$. From the $\mathrm{CPC}$ and EN results, no localized corrosion was found for the stainless steels. However, the reverse was true for the 1018 steel. The EIS results showed that different corrosion mechanism occurred for the carbon steel compared with the stainless steels. This shows that the corrosion mechanism strongly depends on the type of steel. Overall, the 1018 steel exhibited the highest corrosion rate, followed by the 410 alloy. The highest corrosion resistance was achieved by the 800 alloy. In addition, SEM analyses were carried out to explain the experimental findings.
\end{abstract}

Keywords: carbon steel, electrochemical behaviour, stainless steels, synthetic wastewater.

\section{Introduction}

Corrosion is a heterogeneous process involving reactions between a metal with its environment. As corrosion reactions involve the transfer of electrons, corrosion is an electrochemical process of oxidation and reductions reactions [1].

\footnotetext{
* Corresponding author. E-mail address: raul.sandoval@cimav.edu.mx.
} 
Electrochemical measurements are now widely used in most fields of corrosion research [2]. Detailed reviews are available on the application of electrochemical techniques such as linear polarization resistance (LPR) [3-5], polarization curves (Tafel slopes) [6-8], electrochemical noise (EN) [9-15], and electrochemical impedance spectroscopy (EIS) [11,16-19], among others. In wastewater systems both metallic (steel, cast iron, stainless steel) and nonmetallic materials (concrete, ABS, PVC etc.) are widely used. For such systems, various strategies that may be used to prevent or minimize corrosion are better design parameters, modification of the environment and selection of construction materials [20]. Also, coal tar epoxy systems applied to the interior of concrete pipes have been reported [21]. Regarding metallic materials issues, some valuable work has been done to evaluate materials performance in water systems by using various techniques. Korshin [22] and co-workers studied the effect of natural organic matter in potable water on the corrosion of leaded brass using XPS and SIMS techniques. Iversen [23] studied the microbial corrosion of AISI 304 and AISI 316 stainless steels in wastewater treatment plants with the open circuit potential technique (OCP). Tuthill [24] reports polarization curves for as-welded 304L (with heat tint) and as-welded and pickled (heat scale removed) on the corrosion behaviour of austenitic stainless steels in wastewater environments.

Thus, the goal of the present work is to ascertain the corrosion behaviour of three alloys with different chromium content exposed into simulated synthetic waste water by using various electrochemical techniques.

\section{Experimental}

The materials used were carbon steel 1018, a martensitic 410 stainless steel and a austenitic high alloy 800 used typically in high temperature applications. Their chemical compositions are shown in Table 1.

Table 1. Chemical composition of the alloys used / (\% w.t.).

\begin{tabular}{|c|c|c|c|c|c|c|c|c|c|c|c|c|}
\hline $\begin{array}{c}\text { UNS } \\
\text { Number }\end{array}$ & Name & $\mathrm{C}$ & $\mathrm{Mn}$ & $\mathrm{S}$ & $\mathrm{P}$ & $\mathrm{Cr}$ & $\mathrm{Ni}$ & $\mathrm{Si}$ & $\mathrm{Cu}$ & $\mathrm{Mo}$ & $\mathrm{Ti}$ & $\mathrm{Al}$ \\
\hline G10180 & 1018 & $0.15-0.20$ & $0.60-0.90$ & 0.05 & 0.04 & - & - & - & - & - & - & - \\
\hline S41000 & 410 & 0.15 & 1 & 0.03 & 0.04 & $11-13$ & - & 1.0 & - & - & - & - \\
\hline N08800 & 800 & 0.1 & 1.5 & 0.015 & 0.015 & $19-23$ & $30-35$ & 1.0 & 0.75 & - & 0.6 & 0.6 \\
\hline
\end{tabular}

\section{Materials preparation}

Specimens from the various alloys (working electrodes) were cut from rods into coupons. Specimen dimensions were: $1.27 \mathrm{~cm}$ in diameter $\times 2 \mathrm{~cm}$ length for the 1018 steel and 800 alloy; and $0.316 \mathrm{~cm}$ in diameter $\times 2 \mathrm{~cm}$ length for the 410 steel. The specimens were mounted in epoxy resin. After mounting, each specimen was polished up to 1200 grit $\mathrm{SiC}$ paper, washed with distilled water, degreased with acetone and dried prior to the tests. Synthetic wastewater was prepared using $5 \mathrm{~g}$ of ground organic matter dissolved in 1 litre of potable water. Table 2 shows the characterization analysis of synthetic wastewater. 
Table 2. Characteristics of synthetic wastewater.

\begin{tabular}{|c|c|}
\hline Biochemical oxygen demand & $776 \mathrm{ppm}$ \\
\hline Chemical oxygen demand & $1293 \mathrm{ppm}$ \\
\hline Temperature & $21^{\circ} \mathrm{C}$ \\
\hline $\mathrm{pH}$ & 8 \\
\hline
\end{tabular}

\section{Electrochemical techniques}

Electrochemical experiments were carried out using an ACM Gill 8 internal potentiostat, zero resistance ammeter, frequency response analyzer and galvanostat controlled by a personal computer. All the potentials were measured using a saturated calomel electrode (SCE) as reference electrode. The counter electrode was a platinum foil. LPR measurements were carried out by applying a small sweep from -20 to $+20 \mathrm{mV}$ around the rest potential at a scan rate of 1.5 $\mathrm{mV} / \mathrm{s}$.

From the LPR data, corrosion rates were calculated in terms of the corrosion current density, $i_{\text {corr }}$, using the Stearn and Geary [25] equation. The $i_{\text {corr }}$ value was calculated as follows:

$$
i_{\text {corr }}=\frac{26}{R_{p}}
$$

where 26 is a Tafel constant value given by the software used and $R_{p}$ is the polarization resistance. The corrosion rates, in $\mathrm{mm} / \mathrm{year}$, were calculated using Faraday's law. All tests started after 1 hour of exposition.

Cyclic polarization curves were included in this work to evaluate the conditions of passivity and tendency of the metals to suffer local pitting [26]. In this case, the applied potential varied from $-1 \mathrm{~V}$ to $+1 \mathrm{~V}$ at a scan rate of $90 \mathrm{mV} / \mathrm{min}$. EN measurements were based on the ASTM standard [27]. For each alloy, an arrangement of three identical electrodes was used. Signals were collected during 1024 seconds. Experimental Nyquist diagrams were obtained using a small amplitude signal $(\Delta \mathrm{V}=10 \mathrm{mV} \mathrm{rms})$ over a frequency range from $20 \mathrm{mHz}$ to 0.01 Hz. In all cases, the experiments were run at ambient temperature.

\section{SEM observations}

After exposure to the environment, the morphology of the exposed surfaces was observed by conventional scanning electron microscopy (SEM).

\section{Results and discussion \\ LPR Tests}

From the LPR tests, the $\mathrm{E}_{\text {corr }}$ values recorded for the 1018 steel, 410 steel and the 800 steel were, $-272 \mathrm{mV},+102 \mathrm{mV}$, and $-13.3 \mathrm{mV}$, respectively.

Table 3 shows the values of polarization resistance, $i_{\text {corr }}$, and corrosion rates recorded for the various materials. It can be seen that the 1018 alloy disclosed higher corrosion rate than the other alloys. Significant differences were noted 
among the alloys. For instance, the corrosion rate difference between the 1018 carbon steel and the 410 stainless steel was about two orders of magnitude, and between the 1018 carbon steel and the 800 stainless steel it was about three orders of magnitude. It is thought that the higher corrosion resistance of the stainless steels is achieved due to their chromium content.

Table 3. $\mathrm{Rp}, \mathrm{i}_{\text {corr }}$ and corrosion rates obtained from polarization resistance.

\begin{tabular}{|c|c|c|c|}
\hline Alloy & $\begin{array}{c}\text { Polarization resistance/ } \\
/\left(\text { Ohms } . \mathrm{cm}^{2}\right)\end{array}$ & $\begin{array}{c}\mathrm{i}_{\text {corr }} / \\
/\left(\mathrm{mA} / \mathrm{cm}^{2}\right)\end{array}$ & $\begin{array}{c}\text { Corrosion rate } / \\
/(\mathrm{mm} / \text { year })\end{array}$ \\
\hline 1018 & $4.93 \mathrm{E} 03$ & $5.27 \mathrm{E}-03$ & $2.67 \mathrm{E}-02$ \\
\hline 410 & $4.45 \mathrm{E} 05$ & $5.84 \mathrm{E}-05$ & $6.44 \mathrm{E}-04$ \\
\hline 800 & $4.19 \mathrm{E} 06$ & $6.21 \mathrm{E}-06$ & $6.40 \mathrm{E}-05$ \\
\hline
\end{tabular}

CPC tests

The results from the CPC tests (Fig. 1) indicated different behaviour for the alloys. The shape of the anodic curve for the 1018 steel shows a passive like behaviour at above approximately $130 \mathrm{mV}$. To some extent, this could be due to the formation of corrosion products on the steel surface. However, the probability of localized attack is indicated by the hysteresis loop recorded on this steel. The pitting potential, Ep, was reached at about $600 \mathrm{mV}$. The hysteresis loop indicates a poor repassivating ability and a low protection potential, $\mathrm{E}_{\text {prot }}$, of about 400 $\mathrm{mV}$. SEM observations indicated the presence of pits on the steel surface, as can be seen in Fig. 8.

The curves for 410 and 800 steels showed a rather different behaviour. The shape of the anodic curve shows a wide range of passivation potential, being somewhat larger for the 800 alloy, i.e., the breakdown potential for the 410 steel is about $850 \mathrm{mV}$, whereas for the 800 steel was about $1000 \mathrm{mV}$. For these materials, an hystheresis loop was not found. Instead the curves exhibited instantaneous repassivation on the reverse scan. Hence, under the experimental conditions of the present work, the stainless steels used were not susceptible to localized corrosion.

\section{ECN tests}

Potential and current and time records for the three types of steels are shown in Fig. 2, 3 and 4. The DC trend of the signals was removed using the moving average removal [28] method. It can be seen that the amplitude of voltage fluctuations are at least one order of magnitude higher for the 1018 steel as compared to the 410 and 800 alloys. Also, 1018 steel signal displays a different shape with spikes combined with low amplitude and frequency fluctuations. On the other hand, current fluctuations follow the opposite order where fluctuations are much smaller for the 410 and 800 steels than those obtained for the 1018 steel, indicating a less active interface. This is reflected in the standard deviation values of the steels shown in Table 4 . These values allow the calculation of noise resistance, $R_{n}$, for each material from equation

$$
R_{n}=\sigma_{v} / \sigma_{i}
$$


where $\sigma_{\mathrm{v}}$ is the standard deviation of the potential noise and $\sigma_{\mathrm{i}}$ is the standard deviation of the current noise [29].

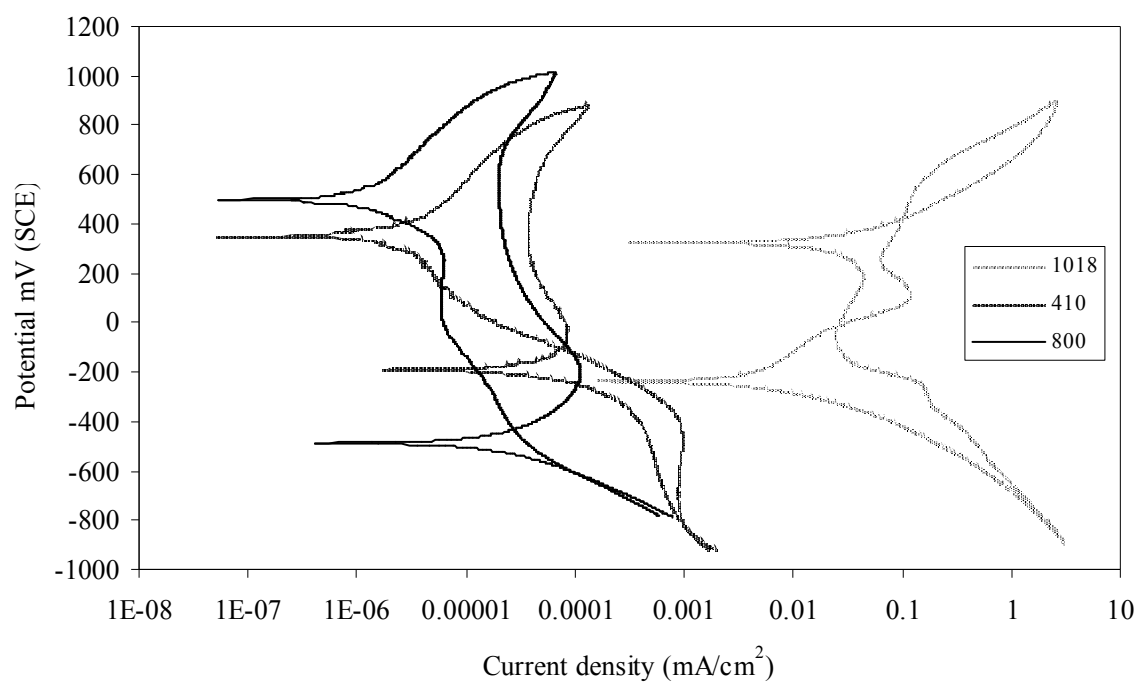

Figure 1. Cyclic potentiodynamic curves for 1018,410 and 800 steels.
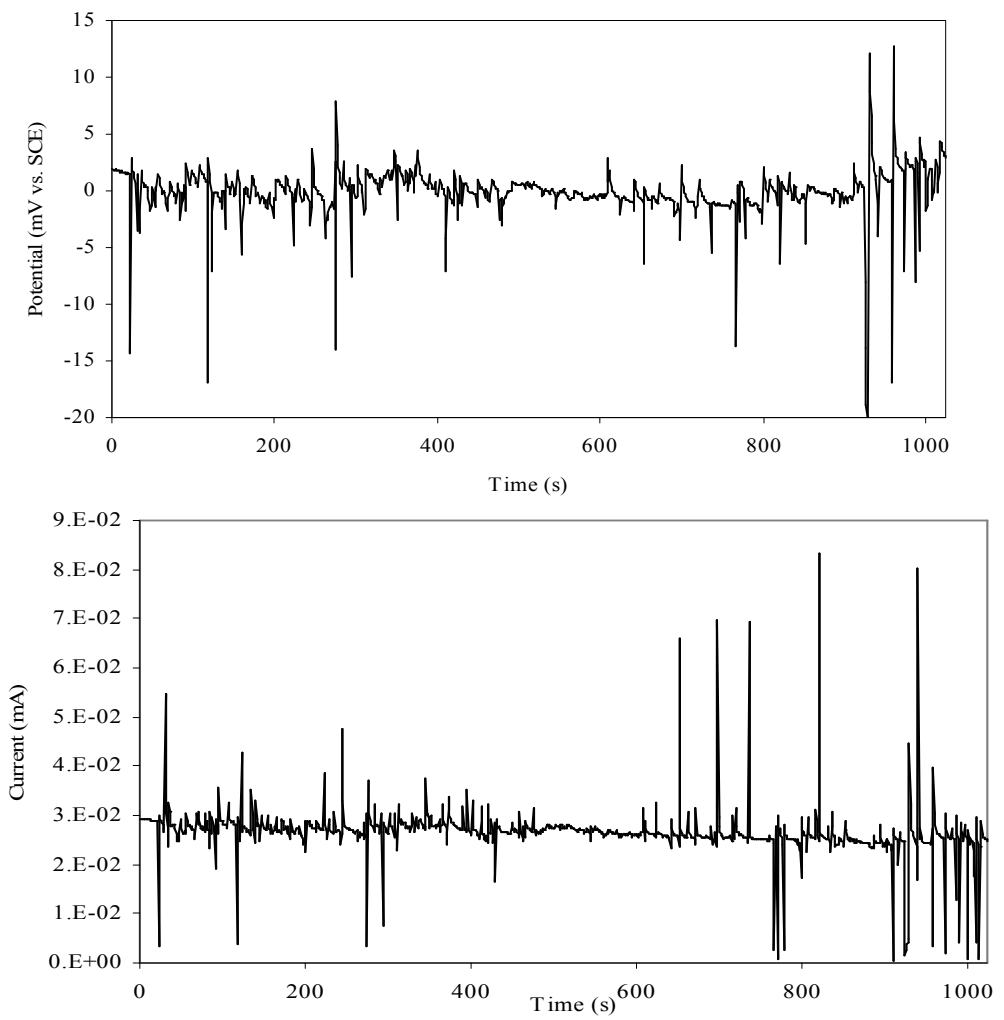

Figure 2. Potential and current time records for 1018 steel in the test solution. 
From these results a performance order can be established, where the 1018 steel shows the lowest resistance and therefore highest corrosion rate and a similar value to that obtained using other techniques. The 410 and 800 steels follow with resistances several orders of magnitude higher than that of the 1018 steel.
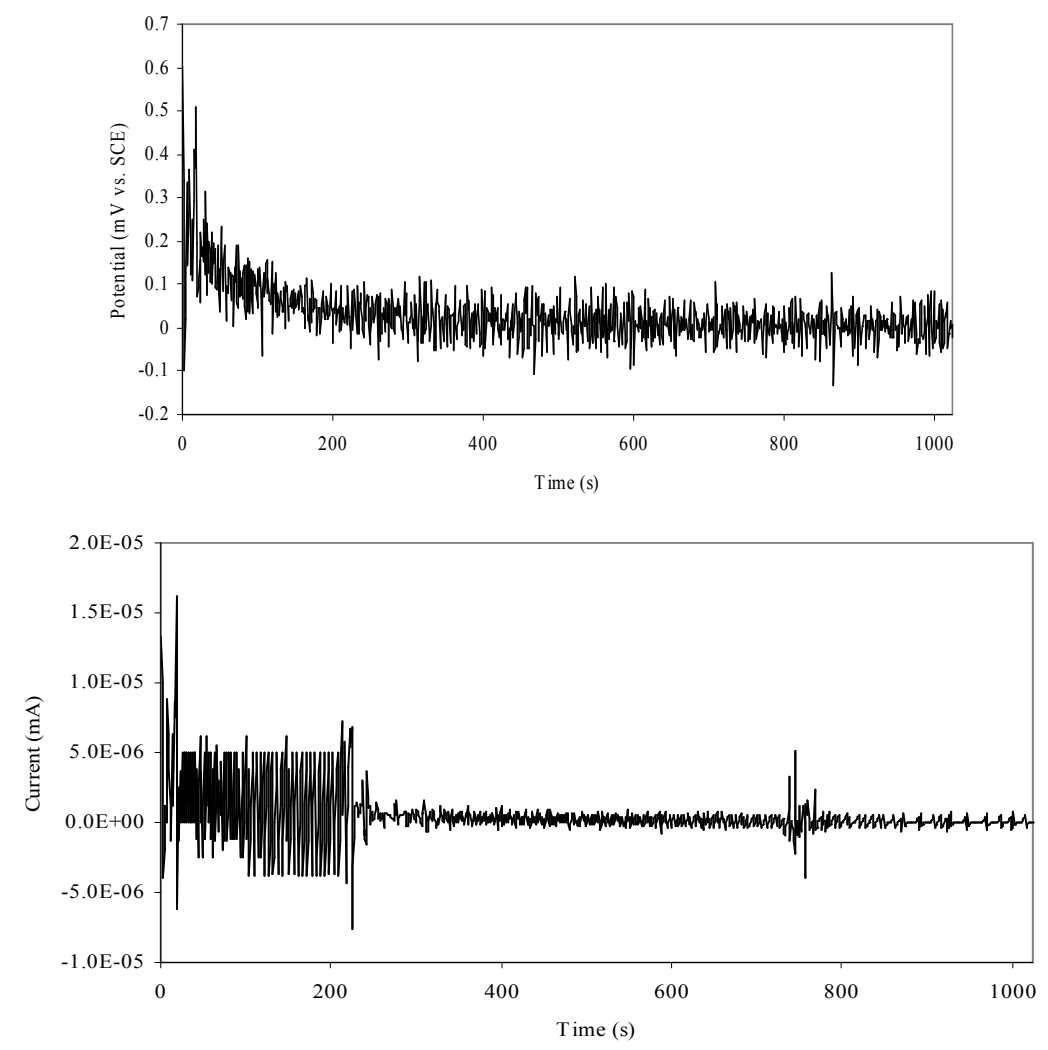

Figure 3. Potential and current time records for 410 steel in the test solution.

Therefore the best corrosion rate behaviour corresponds to the 800 steel followed by the 410 and 1018 steels. Prediction of corrosion rate values using electrochemical noise rates are similar to those obtained by other techniques, apart for the fact that for the 800 steel smaller values are obtained. 

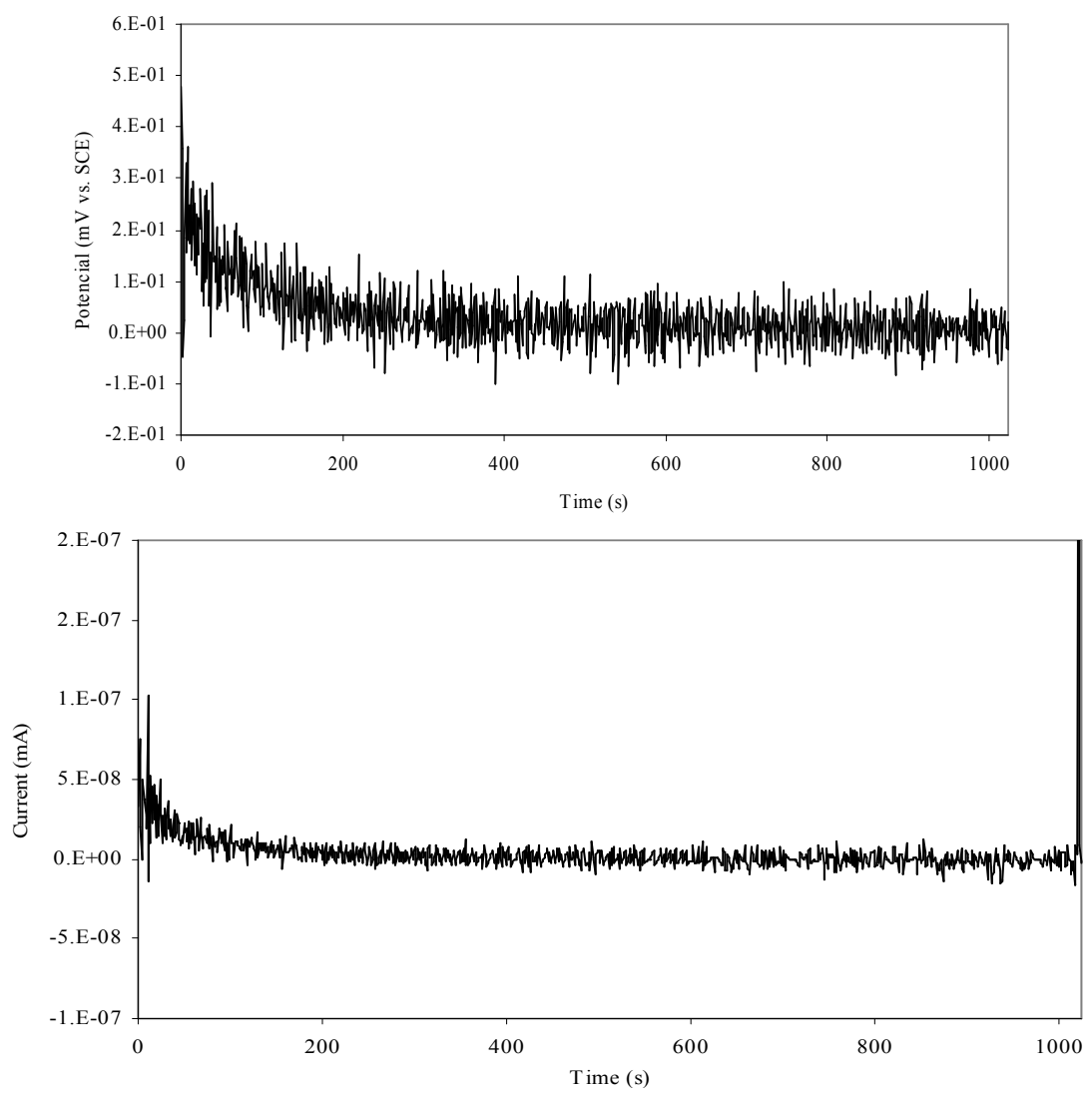

Figure 4. Potential and current time records for 800 steel in the test solution.

Table 4. $\mathrm{Rp}, \mathrm{i}_{\text {corr }}$ and corrosion rates obtained from EIS.

\begin{tabular}{|c|c|c|}
\hline Alloy & $\begin{array}{c}\text { Polarization resistance/ } \\
/\left(\text { Ohms.cm }^{2}\right)\end{array}$ & $\begin{array}{c}\mathrm{i}_{\text {corr }} / \\
/\left(\mathrm{mA} / \mathrm{cm}^{2}\right)\end{array}$ \\
\hline 1018 & $3.55 \mathrm{E} 03$ & $7.32 \mathrm{E}-03$ \\
\hline 410 & $2.4 \mathrm{E} 05$ & $1.08 \mathrm{E}-04$ \\
\hline 800 & $3.1 \mathrm{E} 05$ & $8.38 \mathrm{E}-05$ \\
\hline
\end{tabular}

Regarding the localized nature of the attack, the localization index, L, is defined as

$$
\mathrm{L}=\sigma_{\mathrm{i}} / \mathrm{I}_{\mathrm{rms}}
$$

where $\mathrm{I}_{\mathrm{rms}}$ is the rms value of the current noise. The localization index falls in the range of 0.0 to 1.0 . Values on the order of 0.001 indicate that uniform general corrosion is the predominant mechanism, whereas values approaching 1.0 indicate the predominance of a localized mechanism [30,31]. The localization index was found to differentiate between low corrosion passive behaviour and localized corrosion in this environment. The 410 and 810 alloys materials can be differentiated because their values are closer to 0 and therefore indicate predominance of uniform corrosion; in contrast, L value for 1018 steel is higher closer to 1, which suggests a localized contribution not found in the other steels (see Table 5). This is in agreement with visual observations of the surface. 
Table 5. Electrochemical noise parameters.

\begin{tabular}{|c|c|c|c|c|c|c|}
\hline Alloy & $\sigma_{\mathrm{V}}$ & $\sigma_{\mathrm{i}}$ & $\mathrm{R}_{\mathrm{n}}$ & $\begin{array}{c}\text { Corrosion } \\
\text { rate / (mm-y) }\end{array}$ & $\begin{array}{c}\text { Pit } \\
\text { Index L }\end{array}$ & Description \\
\hline 1018 & 0.859 & $1.37 \mathrm{E}-3$ & 625 & 0.210 & 0.194 & $\begin{array}{c}\text { Uniform } \\
\text { corrosion with } \\
\text { localized } \\
\text { corrosion }\end{array}$ \\
\hline 410 & 0.0343 & $2.58 \mathrm{E}-07$ & 132.300 & 0.0021 & 0.016 & $\begin{array}{c}\text { Predominant } \\
\text { uniform } \\
\text { corrosion }\end{array}$ \\
\hline 800 & 0.0382 & $4.18 \mathrm{E}-09$ & 9.138 .000 & 0.0000292 & 0.009 & $\begin{array}{c}\text { Predominant } \\
\text { uniform } \\
\text { corrosion }\end{array}$ \\
\hline
\end{tabular}

In summary: corrosion parameters were calculated from electrochemical noise measurements, particularly, noise resistance, which is related to the general corrosion rate and the localization index, which indicates the predominant corrosion attack mechanism. Differences were found for the steels under study.

\section{EIS tests}

In order to obtain a better understanding of the mechanisms taking place at the specimen surface, EIS measurements at the corrosion potential were carried out under potentiostatic conditions. The Nyquist diagram obtained for the 1018 steel (Fig. 5) shows a typical Randles circuit. From this diagram, Table 4 shows the estimated value for $\mathrm{Rp}$, and $\mathrm{i}_{\text {corr }}$, which are in good agreement with the values reported in Table 3. The 410 alloy (Fig. 6) shows a depressed semicircle at intermediate frequencies and diffusional behaviour at low frecuencies, probably associated with the formation of a protective oxide thin film.

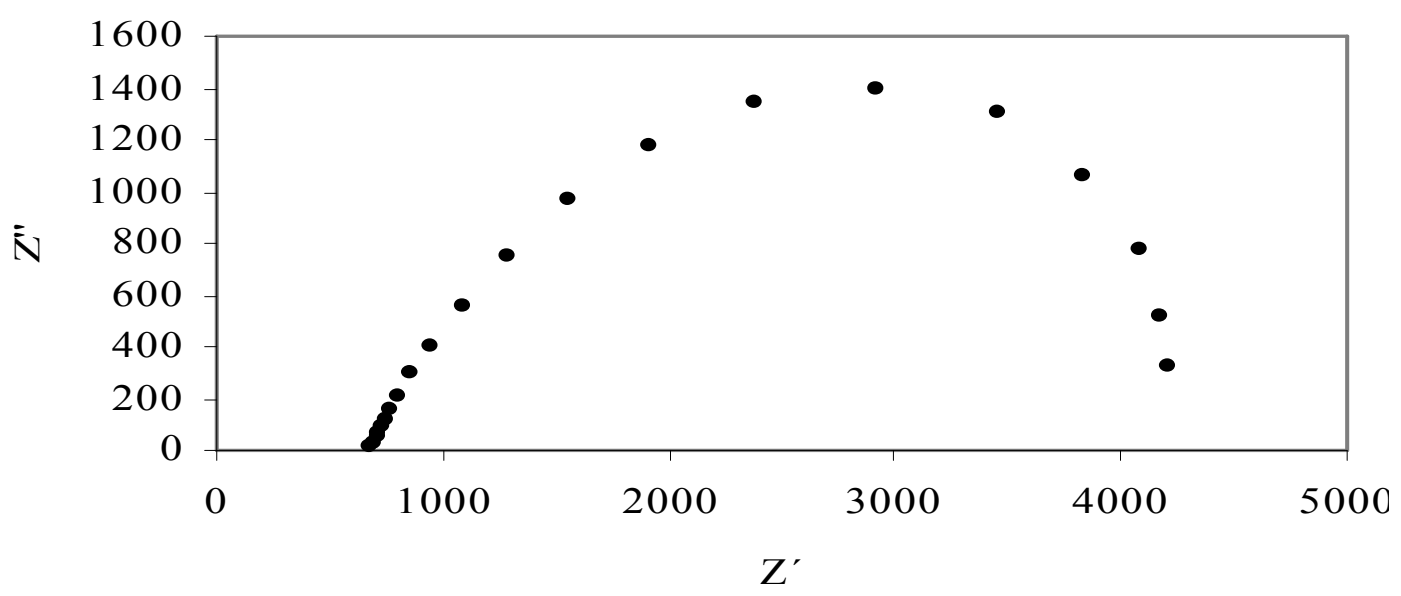

Figure 5. Nyquist diagram for 1018 alloy. 


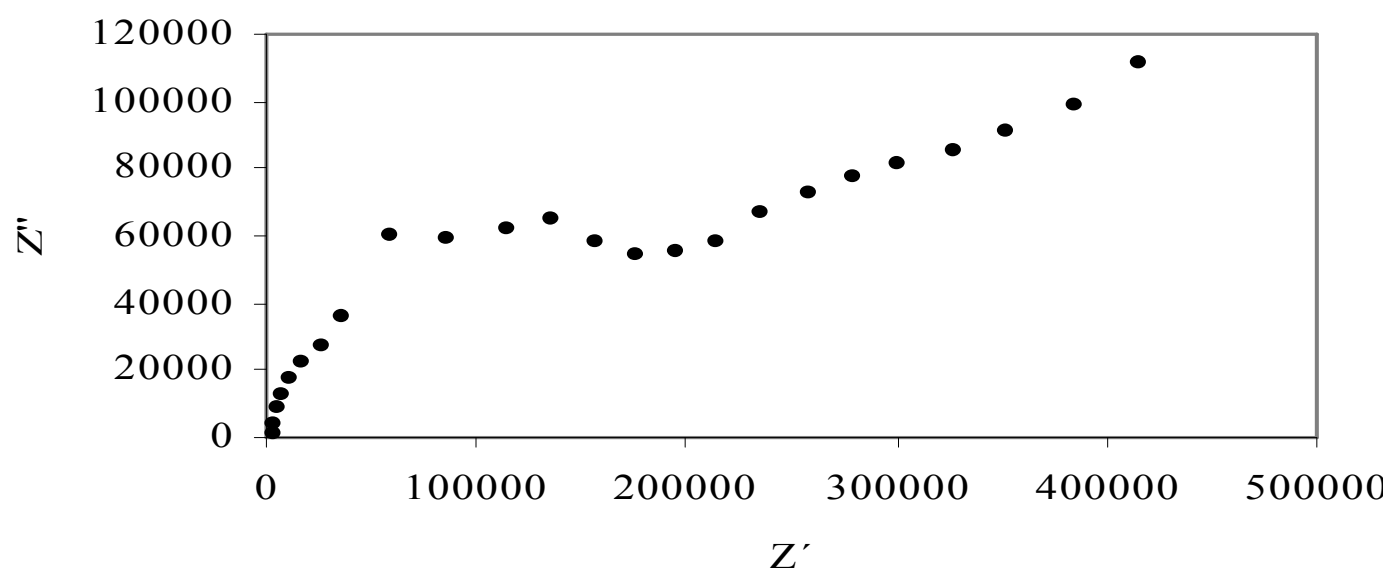

Figure 6. Nyquist diagram of 410 alloy.

Cases like this, when the data do not reach a low frequency limit and show only a partial semicircle have been associated with passive metals [6]. The mechanism observed for the 800 alloy (Fig. 7) is similar to the 410 steel, and in both cases no localized damage could be observed at the alloy surface. This is likely due to the development of a thin protective oxide film on the surface. On both stainless steels, extrapolation of the semicircle depicted in the Nyquist diagrams gives an $\mathrm{Rp}$ value from which $i_{\text {corr }}$ values can be derivate on each case. Again, these values given in Table 4 are in close agreement with the values indicated in Table 3.

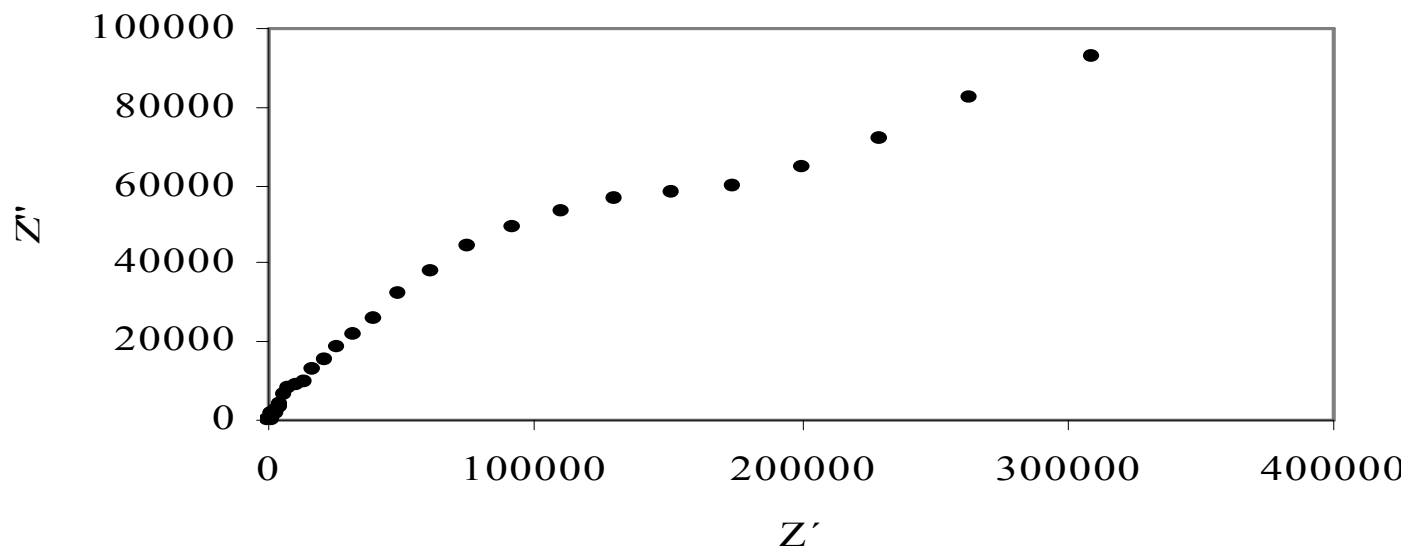

Figure 7. Nyquist diagram of 800 alloy.

\section{SEM observations}

For the 1018 steel, scanning electron microscopy observations showed areas of localized corrosion as pitting, and areas covered with corrosion products, as can be seen in Fig. 8. To some extent, this confirms the CPC and EN results. Observation on the surfaces of the 410 (Fig. 9) and 800 (Fig. 10) steels still showed grinding marks from the specimen preparation, and evidence of pit formation was not observed. It is believed that the chromium content on these 
alloys might induce the formation of a protective oxide film explaining the low corrosion rates measured on these steels.

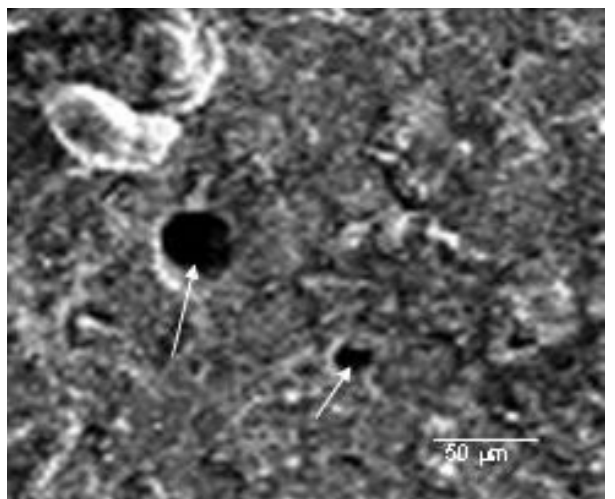

Figure 8. SEM image of the 1018 steel after exposure to the environment showing areas with pitting.

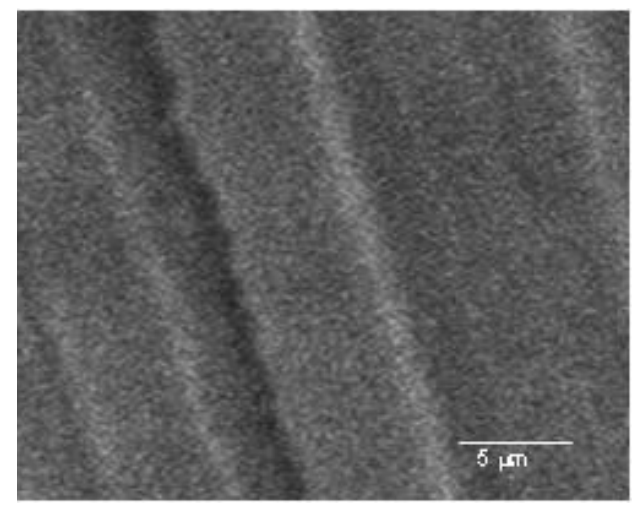

Figure 9. SEM image of the 410 steel after exposure to the environment showing grit lines from initial surface preparation.

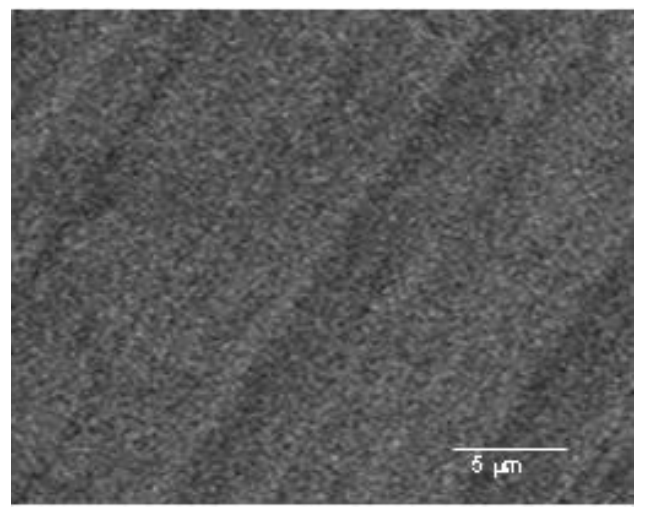

Figure 10. SEM image of 800 steel after exposure to the environment showing grit lines from initial surface preparation. 


\section{Conclusions}

The corrosion behaviour of 1018, 410 and 800 steels exposed to synthetic wastewater was examined using various electrochemical techniques.

LPR results indicated that the 800 steel exhibited the best corrosion resistance, followed by the 410 steel. The highest corrosion rate was for the 1018 steel.

The CPC curves and EN behaviour indicated that the 1018 steel is susceptible to localized corrosion in this environment. The opposite was found for the 410 and 800 alloys.

The EIS results showed that different corrosion mechanisms occurred on the steels. The 1018 steel showed an activation mechanism whereas the stainless steels showed a diffusion mechanism.

It's believed that the chromium content on the stainless steels might develop a protective thin film on the alloy's surface, producing this way a better protection. On the whole, the electrochemical techniques used here were useful to ascertain the corrosion behaviour of steels exposed to a wastewater environment.

\section{Acknowledgements}

The authors are thankful to CONACYT (Mexico) for the financial assistance.

\section{References}

1. B. Pesic and V.C. Storhock, Paper No. 1255, Corrosion 2001, NACE, Houston, Texas.

2. B. Poulson, Corrosion Science 23-4 (1983) 391-430.

3. G. Rocchini, Corrosion Science 34-12 (1993) 2031-2044.

4. G. Rocchini, Corrosion Science 38-12 (1996) 2095-2109.

5. J.R. Scully, Corrosion 56-2 (2000) 199-218.

6. H.W. Pickering, Corrosion Science 23-10 (1983) 1107-1120.

7. B.R. Pearson and P.A. Brook, Corrosion Science 32-4 (1991) 387-398.

8. G. Rocchini, Corrosion Science 38-4 (1996) 655-668.

9. C. Gabrielli, F. Huet, M. Keddam, Corrosion 48-10 (1992) 794.

10. J. Uruchurtu-Chavarín and J.M. Malo, "Electrochemical Noise as a Powerful Electrochemical Technique for Corrosion Research", Research Trends, Trends in Corrosion Research 2 (1997) 49.

11. R. Cottis and S. Turgoose, "Electrochemical Impedance and Noise" serie Corrosion Testing Made Easy, B.C. Syrett Editor, (1999) NACE International, USA.

12. U. Bertocci, F. Huet, B. Jaoul and P. Rousseau, Corrosion 56-7 (2000) 675683.

13. R.A. Cottis, Corrosion 57-3 (2001) 265-285.

14. A. Aballe, A. Bautista, U. Bertocci, F. Huet, Corrosion 57-1 (2001) 35-42.

15. D.A. Eden and G.P. Quirk, Paper No. 1303, Corrosion 2001, NACE, Houston, Texas.

16. D.D. McDonald, Corrosion 46-3 (1990) 229-242.

17. P. Agarwal, O.C. Moghissi, M.E. Orazem and L.H. García-Rubio, Corrosion 49-4 (1993) 278-289. 
18. J.R. Scully, D.C. Silverman, M.W. Kending, Editors, "Electrochemical Impedance, Analysis and Interpretation", ASTM, STP 1188 (1993) USA.

19. L. Domingues, C. Oliveira, J.C.S. Fernandes and M.G.S. Ferreira, Electrochimica Acta 47 (2002) 2253-2258.

20. K.B. Tator, Materials Performance $42-7$ (2003).

21. S.H. Gebler and R.J. Detwiler, Materials Performance 41-7 (2002).

22. G.V. Korshin, J.F. Ferguson and A.N. Lancaster, Corrosion Science 42 (2000) 53-66.

23. A. Iversen, Paper No. 2451, Corrosion 2002, NACE, Denver, Colorado.

24. A.H. Tuthill, Guidelines for the use of stainless steel in municipal waste water treatment plants, NIDI Technical Series No. 10076.

25. M. Stearn and A.L. Geary, J. Electrochem. Soc. 105 (1958) 638.

26. Standard Practice for Conducting Cyclic Potentiodynamic Polarization Measurements for Localized Corrosion, ASTM Standard G61-86, Pennsylvania, p.340.

27. "Electrochemical Noise Measurements for Corrosion Applications" ASTM STP 1277 (West Conshohocken, PA; ASTM 1996) p. 446 - 470.

28. Y.J. Tan, S. Bailey, B. Kinsella, Corrosion Science 38-10 (1996) 16811695.

29. A.N. Rothwell, D.A. Eden, Paper No. 223, Corrosion 92, NACE, Houston, TX .

30. S. Webster, L. Nathanson, A.G. Green, B.V. Johnson, "The use of electrochemical noise to assess inhibitor film stability", Corrosion 92, UK, 1992.

31. J. Mickalonis, R.J. Jacko, G.P. Quirk, D.A. Eden, "The Use of electrochemical noise measurements with nuclear waste tanks, Electrochemical Noise Measurements for Corrosion Applications", ASTM STP 1277, J.R. Kearns, J.R. Scully, P.R. Roberge, D.L. Reichert, J.L. Dawson, Eds., American Society for Testing and Materials, 1996, pp 210213. 